\title{
PERLINDUNGAN HUKUM TERHADAP MAKANAN YANG MENGANDUNG ZAT TERLARANG
}

\author{
Suriani BT Tolo \\ Unsultra Kendari
}

\begin{abstract}
Abstrak
Penelitian ini bertujuan untuk mengetahui dan menjelaskan bagaimana bentuk dan ukuran makanan yang mengandung zat terlarang, untuk mengetahui dan memahami bagaimana perlindungan hukum terhadap makanan yang mengandung zat terlarang dan untuk mengetahui dan menjelaskan bagaimana penyelesaian sengketa kasus makanan yang mangandung zat terlarang. Penelitian ini dilaksanakan di kota kendari, tepatnya pada Kantor Balai POM dan Metode yang digunakan adalah wawancara ( interview ) dan observasi serta melalui kusioner yang dibagikan kepada responden, serta data analisis secara normative. Selanjutnya dianalisa secara deskriptif kuantitatif dan hasil penelitian ini menunjukkan bahwa bentuk dan ukuran suatu makanan yang mengandung zat terlarang dapat diketahui melalui informasi dan iklan yang disampaikan oleh pelaku usaah pada masyarakat dan perlindungan hukum terhadap makanan yang mengandung zat terlarang dapat diselesaikan secara komppromi antara pelaku usaha dan konsumen melalui mediasi Balai POM Kendari yang secara hukum kasus-kasus pelanggaran hukum terhadap makanan yanag mengandung zat terlarang hanya dapat diselesaikan secara kompromi berdasarkan peraturan perundang-undangan yang berlaku

Kata Kunci: perlindungan konsumen, makanan, zat terlarang.
\end{abstract}

\begin{abstract}
This research aims to know and explain how the shapes and the size of food contains forbidden materials, to know and understand how the law protection of consumers against food contains forbidden materials, aand to know and explain how to overcome a case of lawsuit of food that contanins forbidden materials. This research was hejd in Kendari City, it was exactly held in Kendari POM office and the data of this research was received through some methods, they are interviews, some pbservation and questioners given to the respondents, afterwards the data was analyzed juridical normatively. Then, the law protection of comsumers in a case of lawsuit of food contains forbidden materials that is possible to appear in the coming times can be solved through mutual compromise between the businessman ad the consumer under the mediation of Kendari POM institution that actually such problems can only be overcome through a compromise according to the law prevails.
\end{abstract}

Keywords: consumer protection, food, illicit substances.

\section{PENDAHULUAN}

A. Latar Belakang Masalah

Perlindungan konsumen

merupakan salah satu upaya yang menjamin adanya kepastian hukum untuk memberi perlindungan kepada konsumen. Konsumen adalah setiap orang pemakai barang dan atau jasa yang tersedia dalam masyarakat, baik untuk kepentingan diri sendiri, keluarga, orang lain, dan makhluk hidup lain dan tidak untuk diperdagangkan.

Hak-hak konsumen seperti yang tertera dalam UUPK adalah : hak atas kenyamanan, keamanan dan keselamatan dalam mengkonsumsi barang dan/atau jasa; hak atas informasi yang benar, jelas dan jujur mengenai kondisi dan jaminan barang dan jasa; hak didengar pendapat dan keluhannya atas barang dan jasa yang digunakan; hak mendapatkan 
advokasi mengenai perlindungan dan upaya penyelesaian sengketa perlindungan konsumen secara patut; hak mendapat pembinaan dan pendidikan konsumen; hak diperlakukan atau dilayani secara benar dan jujur serta tidak diskriminatif; hak mendapatkan kompensasi, ganti rugi dan/atau penggantian apabila barang dan/atau jasa yang diterima tidak sesuai dengan perjanjian atau tidak sebagaimana mestinya.

Dengan adanya Undang Undang ini pemerintah berupaya untuk mendorong terwujudnya perlindungan konsumen. Karena konsumen dan pelaku usaha merupakan dua kelompok utama yang masing-masing mempunyai kepentingan. Apalagi kepentingan dari para pihak yang tidak dapat berjalan baik, maka kemungkinannya akan timbul konflik diantara keduanya (John Pieris, 2007 : 134).

Kenyataan yang sangat memprihatinkan, justru yang ada di depan mata kita saat ini. Situasi anakanak kita yang juga sebagai konsumen sangat jauh dari situasi terlindungi. Dalam konteks dan kasus konsumen anak saja, dalam beberapa bulan terakhir ini, terpetakan ada banyak sekali kasus yang menunjukkan kondisi anak-anak yang jauh dari terlindungi.

Kasus anak-anak dan makanan misalnya, dari pemberitaan yang ada di media banyak diberitakan bahwa anakanak tidak aman dalam konsumsi pangan antara lain : adanya permen berformalin dari cina yang banyak beredar, adanya anak yang keracunan makanan jajanan, makanan kadaluwarsa, makanan dengan bahan tambahan yang tidak aman dan saat ini masih hangat diberitakan ada banyak makanan dan susu formula dari cina yang mengandung melamin. Sungguh, situasi yang tidak aman untuk anak-anak dan user lainnya yang masuk kategori konsumen.

Harus diakui, tidak semua bahan pengawet berbahaya. Namun, tetap saja, kita harus berhati-hati. Bahan pengawet yang dikatakan aman, jika dikonsumsi melebihi dosis maksimum, tetap berbahaya. Adakah makanan dalam kemasan yang tanpa bahan pengawet. Rasanya pertanyaan tersebut terdengar aneh di zaman sekarang. Betapa tidak, nyaris setiap hari perut kita tak pernah absen menerima pasokan makanan berbahan pengawet.

Pada dasarnya ada beberapa alasan mengapa para produsen makanan mengawetkan produk mereka. Salah satunya karena daya tahan kebanyakan makanan memang sangat terbatas dan mudah rusak (perishable). Pengawetan menjadikan makanan bisa disimpan berhari-hari, bahkan berbulan-bulan. Ini jelas sangat menguntungkan pedagang. Alasan lain, beberapa zat pengawet berfungsi sebagai penambah daya tarik makanan itu sendiri. Seperti penambahan kalium nitrit agar olahan daging tampak berwarna merah segar. Tampilan yang menarik biasanya membuat konsumen jatuh hati untuk membeli.

Secara garis besar zat pengawet dibedakan menjadi tiga jenis. Pertama, GRAS (Generally Recognized as Safe) yang umumnya bersifat alami, sehingga aman dan tidak berefek racun sama sekali. Kedua, ADI (Acceptable Daily Intake), yang selalu ditetapkan batas penggunaan hariannya (daily intake) guna melindungi kesehatan konsumen. Ketiga, zat pengawet yang memang tidak layak dikonsumsi, alias berbahaya seperti boraks, formalin, dan rhodamin $B$. Formalin, misalnya, bisa menyebabkan kanker paru-paru, gangguan pada alat pencernaan dan jantung. Sedangkan penggunaan boraks sebagai pengawet makanan dapat menyebabkan gangguan pada otak, hati, dan kulit.

Dengan demikian, ada baiknya kita lebih berhati-hati dalam menggunakan bahan pengawet, seperti halnya formalin dan boraks yang belakangan marak dibicarakan orang, yang banyak terdapat dalam mi, tahu, dan 
ikan asin yang bisa membahayakan kesehatan konsumen.

Sebenarnya, tanpa bahan pengawet kimia yang berefek racun, seperti halnya formalin, masyarakat bisa melakukan pengawetan dengan memanfaatkan bahan alami. Salah satunya adalah menggunakan garam $(\mathrm{NaCl})$. Cara ini sudah dilakukan bertahun-tahun dalam masyarakat kita. Larutan garam yang masuk ke dalam jaringan diyakini mampu menghambat pertumbuhan aktivitas bakteri penyebab pembusukan, sehingga makanan tersebut jadi lebih awet. Prosesnya biasa disebut dengan pengasinan (curing) atau penggaraman (maka lahirlah istilah ikan asin).

Pengawetan dengan garam ini memungkinkan daya simpan yang lebih lama dibanding dengan produk segarnya yang hanya bisa bertahan beberapa hari atau jam. Contohnya ikan yang hanya tahan beberapa hari, bila diasinkan bisa disimpan selama berminggu-minggu. Tentu saja prosedur pengawetan ini perlu mendapat perhatian karena konsumsi garam secara berlebihan bisa memicu penyakit darah tinggi. Apalagi jika keluarga si anak memiliki riwayat hipertensi.

Metode lain yang dianggap aman adalah pengawetan dengan menyimpan bahan pangan tersebut pada suhu rendah. Suhu di bawah $0^{\circ} \mathrm{C}$ mampu memperlambat reaksi metabolisme, di samping mencegah perkembangbiakan mikroorganisme yang bisa merusak makanan.

Cara lain yang juga kerap dilakukan untuk mengawetkan makanan adalah pengeringan karena air bebas merupakan faktor utama penyebab kerusakan makanan. Semakin tinggi kadar air dalam makanan tertentu, semakin cepat proses kerusakannya. Melalui proses ini, air yang terkandung dalam bahan makanan akan diminimalkan. Dengan begitu, mikroorganisme perusak makanan tidak bisa berkembang biak.

\section{B. Bentuk dan Ukuran makanan yang mengandung zat terlarang.}

Penelitian yang hendak saya teliti adalah makanan yang mengandung formalin. Formaldehid adalah senyawa organik dengan struktur $\mathrm{CH}_{2} \mathrm{O}_{1}$ dihasilkan dari pembakaran tak sempurna dari sejumlah senyawa organik. Terdapat dalam asap batubara dan kayu, terutama asap yang dihasilkan untuk mengasapi daging babi dan ikan. Ditemukan di udara, terutama kota-kota besar. Dibuat secara komersial menggunakan oksidasi fase uap katalitik metanol menggunakan udara sebagai pengoksidasi dan perak, tembaga, alumina, atau batu arang sebagai katalisnya.

Formaldehid merupakan senyawa kimia berbentuk gas atau larutan dan ke dalamnya ditambahkan metanil 10-15\% untuk mencegah polimerisasi. Dalam perdagangan, tersedia larutan formaldehid $37 \%$ dalam air yang dikenal sebagai formalin. Larutan ini mempunyai sifat tidak berwarna atau hampir tidak berwarna seperti air, sedikit asam, baunya sangat menusuk dan korosif, terurai jika dipanaskan dan melepaskan asam formiat. Formaldehid merupakan reduktor kuat yang bereaksi kuat dengan bahan pengoksidasi dan berbagai senyawa organik. Bereaksi dengan asam klorida menghasilkan senyawa bisklorometil eter (BCME) yang sangat beracun. Formalin memiliki titik didih $101^{\circ} \mathrm{C}$; $\mathrm{pH} 2,8-4,0$; densitas 1,067 (udara $=1) ; \mathrm{pKa}=13,27$ pada suhu $25^{\circ} \mathrm{C}$; titik nyala $85^{\circ} \mathrm{C}$ (kelas III A); titik beku $117^{\circ} \mathrm{C}$; tekanan uap $3,890 \mathrm{mmHg}$ pada suhu $25^{\circ} \mathrm{C}$; larut dalam alkohol, eter, aseton dan benzene. Kelarutan dalam air : $4 \times 10^{5} \mathrm{mg} / \mathrm{L}$ pada suhu $20^{\circ} \mathrm{C}$.

Formalin dikenal luas sebagai pembunuh hama (disinfectant) dan pengawet specimen (fiksatif), dan banyak digunakan dalam industri termasuk industri plywood sebagai perekat. Sejauh 
ini pemanfaatannya tidak dilarang namun setiap pekerja yang terlibat dalam pengangkutan dan pengolahan bahan ini harus ekstra hati-hati mengingat risiko yang berkaitan dengan bahan ini cukup besar. Formalin 2-8\% digunakan sebagai germisida.

Formalin jika tertelan dapat menyebabkan rasa terbakar pada mulut dan tenggorokan, jika terhirup sangat berbahaya dalam jangka lama dapat menyebabkan kanker hidung. Formalin juga dapat menyebabkan kelainan genetika pada manusia.

Penggunaan formalin yang salah (misuse) kerap kali dilakukan dalam mengawetkan pangan walaupun senyawa ini sesungguhnya dilarang (mengingat bahayanya) untuk digunakan sebagai pengawet pangan. Praktek yang salah semacam ini dilakukan oleh produsen pangan yang sering mengandung formalin meliputi ikan asin, ikan segar, ayam potong, mie basah dan tahu yang beredar di pasaran. Tetapi perlu diingat bahwa tidak semua produk pangan mengandung formalin. Dan nama Lain formalin adalah Formoform :

Methylene oxide, Formalith : Morbicid, Formic aldehyde : Oxymethylene, Formol: Oxomethylene, Ivalon : Paraform, Karsan : Polyoxymethylene, Lysoform : Superlysoform, Methyl aldehyde : Trioxane, Methylene glycol : Veracur.

\section{Perlindungan Hukum terhadap makanan yang mengandung zat terlarang.}

Membahas

tentang perlindungan hukum terlebih dahulu penulis akan menguraikan mengenai efektivitas hukum itu sendiri. Menurut Pariarata (1989:15), efektivitas berarti pengukuran tercapainya sasaran atau tujuan yang telah ditentukan sebelumnya, sedangkan efektif lebih terarah pada tujuan yang dicapai tanpa mementingkan pengorbanan yang dikeluarkan.
Studi efektivitas hukum adalah suatu strategi perumusan masalah yang bersifat umum yaitu perbandingan antara realitas hukum dengan idealitas hukum. Secara khusus, terlihat jenjang antara hukum dalam tindakan (law in action) dengan hukum dalam teori (law in book).

Soemardjan (Soerjono

Soekanto, 1989:45) mengatakan bahwa efektivitas hukum berkaitan erat dengan faktor-faktor sebagai berikut :

1. Usaha menanamkan hukum di dalam masyarakat, yaitu penggunaan tenaga manusia, alat-alat, organisasi, menghargai, mengakui dan mentaati hukum;

2. Reaksi masyarakat yang didasarkan pada sistem nilainilai yang berlaku. Artinya, masyarakat mungkin menolak atau menentang hukum karena compliance, identification, internalization atau kepentingan mereka terjamin sepenuhnya;

3. Jangka waktu penanaman hukum yaitu panjang atau pendeknya jangka waktu dimana usaha-usaha menanamkan itu dilakukan dan diharapkan memberikan hasil.

Soerjono Soekanto (Otje Salman, 1989:63) dalam Pidato Pengukuhannya sebagai Guru Besar Fakultas Hukum Universitas Indonesia pada tahun 1977, mengatakan bahwa efektivitas hukum ditentukan oleh 5 (lima) faktor, yaitu :

1. memenuhi syarat yuridis, sosiologis, filosofis;

2. penegak hukumnya, misalnya betul-betul telah melaksanakan tugas dan kewajibannya sebagaimana yang digariskan oleh hukum yang berlaku; 
3. fasilitasnya, misalnya prasarana yang mendukung dalam proses penegakan hukumnya;

4. kesadaran hukum masyarakat;

5. budaya hukumnya, misalnya perlu adanya budaya malu (shame culture) dan budaya rasa bersalah (guilty feeling) bilamana seseorang melakukan pelanggaran terhadap hukum yang berlaku.

Mengenai faktor pertama di atas, oleh Soerjono Soekanto (1980:13) dijelaskan lebih jauh sebagai berikut :

1. Berlaku secara yuridis, apabila penentuannya didasarkan pada kaidah yang lebih tinggi tingkatannya, atau bila terbentuk menurut cara yang telah ditetapkan, atau apabila menunjukkan hubungan keharusan antara suatu kondisi dan akibatnya;

2. Berlaku secara sosiologis, apabila kaidah tersebut efektif, artinya dapat dipaksakan berlakunya oleh penguasa walaupun tidak diterima oleh masyarakat (teori kekuasaan), atau kaidah tadi berlaku karena diterima dan diakui oleh masyarakat (teori pengakuan);

3. Berlaku secara filosofis, artinya sesuai dengan cita-cita hukum sebagai nilai positif tertinggi.

Keberlakuan secara filosofis suatu peraturan perundangundangan mengandung makna bahwa aturan itu mengandung "nilai dasar keadilan" atau memberi jaminan terwujudnya nilai-nilai keadilan pada masyarakat. Sedangkan keberlakuan secara sosiologis mengandung makna bahwa aturan itu mengandung "nilai dasar kemanfaatan" atau memberi manfaat terhadap perorangan dan kepentingan umum. Sementara keberlakuan secara yuridis mengandung makna bahwa aturan itu mengandung "nilai dasar kepastian hukum". Dengan demikian, hubungan antara keberlakuan hukum dan nilai-nilai dasar hukum merupakan hubungan sebab akibat.

Pandangan di atas sejalan dengan yang dikatakan Gustav Radbruch bahwa terdapat tiga nilai dasar hukum yaitu keadilan, kemanfaatan dan kepastian hukum, yang sekaligus menjadi tempat tujuan berlabuhnya hukum itu. Suatu produk hukum yang dirasakan tidak memberikan keadilan, kemanfaatan dan kepastian hukum maka produk hukum tersebut tidak efektif. Dalam kaitan dengan pokok pembahasan pada penelitian ini yakni terkait dengan masalah efektivitas perundang-undangan pangan, maka perundang-undang ini akan efektif apabila kita melihat bahwa produk pangan yang beredar di pasaran saat ini sudah memberikan jaminan keamanan (tidak mengandung Formalin, Boraks dan Rhodamin B). Berangkat dari uraian tersebut di atas, maka fokus pembahasan pada sub bab ini adalah mengenai salah satu unsur efektivitas/nilai dasar hukum yakni nilai dasar kemanfaatan (aspek manfaat) dari eksistensi perundangundangan pangan terhadap perlindungan konsumen di Kota Kendari, khususnya terhadap peredaran pangan yang mengandung bahan berbahaya dan beracun (Formalin, Boraks dan Rhodamin B).

Penulisan mengenai

kemanfaatan keberadaan perundang-undangan Pangan di masyarakat sangat penting, mengingat ada sebuah adagium yang terkenal het recht hink achter 
de feiten aan (hukum tertatih-tatih mengejar perubahan zaman). Penulis akan meneliti lebih lanjut apakah perundang-undangan pangan masih sesuai dengan kondisi masyarakat saat ini ataukah sudah harus dilakukan perubahan (revisi).

Adapun indikator-indikator yang penulis angkat untuk menguji efektivitas perundang-undangan pangan adalah seputar implementasi hak-hak konsumen yang meliputi hak atas produk yang aman dan hak atas informasi produk. Dengan pengujian indikator tersebut, tentunya akan diketahui sejauh mana manfaat yang dirasakan konsumen dari keberadaan perundang-undangan pangan terhadap produk pangan (IRT) yang beredar di Kota Kendari.

1. Pengetahuan konsumen akan Hak yang dimiliki

Dalam pasal 6 UU Pangan 1996 dinyatakan bahwa : “Setiap orang bertanggung jawab dalam penyelenggaraan kegiatan atau proses produksi, penyimpanan, pengangkutan, dan atau peredaran pangan wajib:

a. Memenuhi persyaratan
sanitasi, keamanan, dan atau
keselamatan manusia;
b. Menyelenggarakan program
pemantauan sanitasi secara
berkala;
c. Menyelenggarakan
pengawasan atas pemenuhan
persyaratan sanitasi".
Untuk mengetahui sejauh mana manfaat yang telah dirasakan oleh konsumen, terlebih dahulu perlu diketahui seberapa jauh tingkat pengetahuan konsumen. Berikut ini penulis menampilkan tabel mengenai tingkat pengetahuan konsumen mengenai keberadaan hak-haknya.

\section{Kepatuhan Hukum Pelaku Usaha \\ Pelaku usaha diharapkan} dapat melakukan aktivitas usahanya dalam rambu-rambu hukum pangan (UU Pangan 1996 beserta peraturan pelaksanaannya). Suasana kondusif ini akan tercipta apabila pelaku usaha memiliki kesadaran hukum dan itu diimplementasikannya menjadi sebuah perilaku hukum atau kepatuhan hukum.

Sebagaimana telah dikemukakan sebetulnya bahwa terdapat 4 (empat) indikator kesadaran hukum, yang masingmasing akan menjadi suatu tahapan ke tahapan berikutnya, yakni :

1. Pengetahuan tentang peraturanperaturan hukum (law awareness)

2. Pengetahuan tentang isi peraturan hukum/pemahaman hukum (law acquaintance)

3. Sikap terhadap peraturanperaturan hukum (legal attitude)

4. Perilaku hukum (legal behavior).

\section{Pengetahuan Hukum}

Beberapa aturan hukum positif yang mengatur mengenai Bahan Tambahan Pangan antara lain :

1) Permenkes Nomor 722/Menkes/Per/IX/88 tentang Bahan Tambahan Pangan.

2) Permenkes Nomor 239/Menkes/Per/V/85 tentang Zat Warna Tertentu yang Dinyatakan Sebagai Bahan Berbahaya.

3) UU Nomor 7 Tahun 1996 tentang Pangan.

4) Peraturan Pemerintah Nomor 28 Tahun 2004 tentang Mutu, Gizi dan Keamanan Pangan. 
Keempat aturan tersebut secara ringkas mengatur mengenai penggunaan bahan tambahan pangan serta tanggung jawab pelaku usaha dalam peredaran pangan untuk memenuhi persyaratan sanitasi, keamanan, dan atau keselamatan manusia.

Dalam Pasal 21 UU Pangan 1996 ditegaskan bahwa : "Setiap orang dilarang mengedarkan pangan yang mengandung bahan beracun, berbahaya, atau yang dapat merugikan atau membahayakan kesehatan atau jiwa manusia,...... sehingga menjadikan pangan tidak layak dikonsumsi manusia".

Pelanggaran ketentuan ini apabila dilakukan dengan sengaja maka dipidana dengan pidana penjara paling lama 5 tahun dan atau denda paling banyak 600 juta dan apabila karena kelalaiannya di pidana dengan pidana penjara paling lama 1 tahun dan atau denda maksimal 120 juta (Pasal 55, 56 UU Pangan 1996).

Penulis menelusuri tingkat pengetahuan hukum pelaku usaha pangan IRT dengan mengajukan pertanyaan tentang pengetahuan mereka tentang standarisasi keamanan pangan (larangan penggunaan Formalin, Boraks maupun Rhodamin B dalam pangan) sebagaimana telah diatur dalam peraturan perundang-undangan.

\section{Peran Pemerintah dalam Penegakan Undang-Undang Pangan}

Masalah terakhir yang diteliti adalah peran aparat pemerintah/penegak hukum dalam proses penegak hukum di bidang pangan. Institusi yang dipilih adalah
Balai Pengawasan Obat dan Makanan (POM) Kendari. Namun mengingat kasus peredaran pangan dengan penggunaan Formalin, Boraks dan Rhodamin B tidak ada yang dimeja-hijaukan, maka pembahasan dan analisis data pada sub bab ini difokuskan pada Balai POM Kendari.

Berdasarkan Keputusan

Presiden Nomor 103 Tahun 2001 tentang Kedudukan, Tugas, Fungsi, Kewenangan, Susunan Organisasi dan Tata Kerja Lembaga Pemerintah Non Departemen (LPND), Badan POM (termasuk Balai POM) ditetapkan sebagai LPND yang bertanggung jawab langsung kepada Presiden. Adapun tugas Badan POM adalah melaksanakan tugas pemerintahan di bidang pengawasan obat dan makanan sesuai dengan peraturan perundang-undangan yang berlaku. Sedangkan fungsinya sebagai berikut :

1. Pengkajian dan penyusunan kebijakan nasional di bidang pengawasan obat dan makanan.

2. Pelaksanaan kebijakan tertentu di bidang pengawasan obat dan makanan.

3. Koordinasi kegiatan fungsional dalam pelaksanaan tugas Badan POM.

4. Pemantauan, pemberian bimbingan dan pembinaan terhadap instansi pemerintah dan masyarakat di bidang pengawasan obat dan makanan.

5. Penyelenggaraan pembinaan dan pelayanan administrasi umum di bidang perencanaan umum, ketatausahaan, organisasi dan tatalaksana, kepegawaian, keuangan, kearsipan, hukum, persandian, perlengkapan dan rumah tangga.

Sementara kewenangan

Badan POM sebagai berikut : 
1. Penyusunan rencana nasional secara makro di bidangnya.

2. Perumusan kebijakan di bidangnya untuk mendukung pembangunan secara makro.

3. Penetapan sistem informasi di bidangnya.

4. Penetapan persyaratan penggunaan bahan tambahan pangan (zat adiktif) tertentu untuk makanan dan penetapan pedoman pengawasan peredaran obat dan makanan.

5. Pemberian izin dan pengawasan peredaran obat serta pengawasan industri farmasi.

6. Penetapan pedoman penggunaan konservasi, pengembangan dan pengawasan obat.

Untuk

mendukung pelaksanaan tugas dan fungsi tersebut, maka ditetapkan Struktur Organisasi Badan POM berdasarkan Keputusan Presiden Nomor 110 Tahun 2001, yakni terdiri dari Kepala, Sekretariat Utama, Deputi Bidang Pengawasan Produk Terapetik dan Narkotika, Psikotropika dan Zat Adiktif, Deputi Bidang Pengawasan Obat Tradisional, Kosmetik dan Produk Komplemen, Deputi Bidang Pengawasan Keamanan Pangan dan Bahan Berbahaya.

Berdasarkan hasil

wawancara penulis dengan pihak Balai POM Kendari, yang diwakili oleh Drs. Ahmad Yani, Apt (Kepala Seksi SERLIK), tanggal 15 Juli 2009, disebutkan bahwa ada beberapa kewenangan yang dimiliki oleh Balai POM diantaranya adalah :

1. Melakukan Pemeriksaan sarana produksi dan distribusi OMKABA.

2. Melaksanakan pemeriksaan dan pengawasan terhadap pengadaan pangan.
3. Melaksanakan tindak lanjut keputusan tentang pengamanan produk/penghentian kegiatan sarana produksi dan distribusi makanan.

4. Melaksanakan kegiatan sampling di toko, supermaket, dan tempat usaha lainnya.

5. Melaksanakan pengawasan periklanan dan cara-cara promosi makanan/minuman.

Terkait dengan kerangka penulisan ini, oleh Kepala Badan POM RI, Drs. H. Sampurno, MBA mengatakan bahwa penyalahgunaan Formalin dan Boraks sebagai pengawet makanan serta Rhodamin B sebagai pewarna makanan lebih disebabkan oleh oversupply, tersedia secara Was dan bebas diperjualbelikan secara eceran, dengan harga murah dan mudah didapatkan. Sehubungan dengan ha! tersebut, maka langkah awal yang telah dilakukan oleh Balai POM Kendari terhadap penanganan beredarnya beberapa jenis pangan produksi IRT yang mengandung Formalin, Boraks dan Rhodamin B adalah melakukan pengujian atas beberapa sampel pangan.

Menurut Penulis, fenomena tersebut lebih disebabkan oleh 3 (tiga) faktor yakni desakan ekonomi, proses pengkomunikasian (sosialisasi) hukum dan pengawasan yang belum maksimal dilaksanakan.

Pandangan penulis didukung pula oleh Dra. Fauzia Idrus, Apt (Kepala Seksi Pengujian Pangan dan Bahan Berbahaya), dimana menurut beliau bahwa maraknya peredaran pangan yang menggunakan Formalin, Boraks dan Rhodamin B disebabkan karena belum tersosialisasinya dengan baik perundang-undang pangan tersebut, koordinasi dengan sektor terkait masih belum optimal, serta tingkat 
kesadaran hukum pelaku usaha pangan yang rendah.

Sebagai contoh faktual, Beliau menyebutkan 3 (tiga) toko di Kota Kendari yang menjual/menyediakan bahan tambahan pangan yang dilarang berupa Formalin, Boraks dan Rhodamin B. 2 (dua) diantaranya menjual secara langsung "Bleng" (Boraks) dan Rhodamin B (dalam kemasan kaleng), sementara 1 (satu) toko lainnya selain menjual "ansac" (formalin) dalam bentuk aslinya, juga menjual mie yang sudah dicampur dengan ansac.

Fenomena demikian memang harus segera ditangani secara sinergis oleh komponenkomponen yang terkait. "pelecehan" hak-hak konsumen seyogyanya harus dihentikan sesegera mungkin. Aturan hukum harus tetap ditegakkan sesuai substansinya. Namun penulis tetap menyadari bahwa penegakan hukum pangan bagi perlindungan konsumen tidak semudah membalikkan telapak tangan. Terasa sulit, hal ini disebabkan desakan sub sistem non hukum seperti ekonomi, sosial dan budaya. Pemerintah/penegak hukum kesulitan untuk melakukan pendekatan hukum mengatasi masalah ini "buah simalakama", apabila aparat mau konsisten menegakkan perundang-undangan pangan tersebut, karena dapat dipastikan dunia usaha, khususnya usaha-usaha IRTP akan redup.

Hal tersebut senada dengan yang dikatakan oleh Dra. Mirnawati Purba, Apt (Kepala Seksi Pemeriksaan dan Penyidikan), bahwa banyak pelaku usaha akan "gulung tikar" khususnya kalangan pengusaha kecil (pelaku usaha pangan IRT) apabila kegiatan usaha kesehariannya dilakukan dengan pendekatan hukum. Oeh karena itu
Beliau mengatakan, bahwa selama ini Balai POM dalam menyikapi kasus peredaran pangan yang menggunakan Formalin, Boraks maupun Rhodamin B masih dalam taraf tindakan administrasi sebagaimana diatur dalam Pasal 54 ayat (2) UU Pangan 1996. Sanksi yang diberikan kepada pelaku usaha pangan (IRT) meliputi teguran lisan, peringatan secara tertulis, perintah untuk menarik produk pangan dari peredaran hingga pemusnahan produk pangan.

Pemberian sanksi dimaksud didasarkan pada pertimbangan bahwa UU Pangan 1996, UU Kesehatan 1992, Permenkes Nomor 722/Menkes/Per/IX/88 tentang Bahan Tambahan Pangan dan Permenkes Nomor 239/Menkes/Per/V/85 tentang Zat Warna Tertentu yang Dinyatakan Sebagai Bahan Berbahaya, belum tersosialisasi dengan maksimal kepada pelaku usaha pangan IRT. Diharapkan pula, pemberian sanksi dimaksud dapat mengandung pelajaran terhadap peningkatan tanggung jawab dan kepatuhan pelaku usaha atas standar keamanan yang berlaku, sebagaimana sasaran strategis yang hendak dicapai oleh Balai POM dalam rangka mewujudkan perannya sebagai penjamin keamanan peredaran pangan.

Jika menganalisa tindakan hukum yang diambil oleh Balai POM Kendari yang hanya memberikan tindakan administrasi kepada pelaku usaha, sangat tidak setimpa! jika dibandingkan dengan kerugian yang harus diderita oieh konsumen. Konsumen telah mengkonsumsi makanan yang sudah tidak layak untuk dikonsumsi, dan ini sangat berbahaya untuk kesehatan jiwanya yang bisa mengakibatkan kematian. 
Secara langsung memang jarang kita temukan derita yang langsung dialami oleh konsumen, namun hal ini dirasakan setelah jangka waktu yang lama. Tanpa sadar bibit penyakit telah bersemayam subur dalam tubuhnya.

Padahal

penggunaan

perundang-undangan secara sadar oleh Pemerintah sebagai suatu sarana untuk melakukan tindakan-tindakan sosial yang terorganisir merupakan ciri Negara Modern (welfare state). Oleh karena itu, setiap produk hukum yang dikeluarkan oleh Pemerintah sebagai alat untuk mengubah masyarakat haruslah mencerminkan keadilan, kemanfaatan dan kepastian hukum di dalamnya, agar masyarakat senantiasa merasa aman dalam menghadapi perubahan.

Dari temuan di atas, penulis berpendapat bahwa wajah penegakan hukum di bidang pangan masih suram. Padahal jika dicermati ketentuan Pidana baik dalam UU Pangan 1996, Permenkes Nomor 722/Menkes/Per/IX/88 maupun Permenkes Nomor 239/Menkes/Per/V/85 disebutkan bahwa barang siapa dengan sengaja mengedarkan pangan yang mengandung bahan beracun, berbahaya atau yang dapat merugikan atau membahayakan kesehatan \& jiwa manusia, sehingga menjadikan pangan tidak layak dikonsumsi manusia, diancam pidana bagi pelanggarnya yang dengan sengaja adalah 5 tahun pidana penjara, dan atau denda maksimal 600 Juta, sedangkan bagi yang lalai paling lama 1 tahun pidana penjara dan atau denda maksimal 120 Juta.

Hukum tidak akan menjadi instrumen yang baik dalam menciptakan suatu equilibrium sosial selama tidak digunakan oleh seluruh komponen masyarakat dan yang utama adalah Pemerintah. Sebab hanya Pemerintah yang memiliki kekuatan eksternal dari hukum itu berupa penerapan sanksi. Bagaimanapun, sanksi pidana yang diterapkan itu sedikitnya akan mampu membuat perasaan "ngeri" dan "jera" bagi yang mengalaminya, dan menjadi alat kontrol bagi yang lainnya. Ada baiknya kalau kita menyimak apa yang pernah dikatakan oleh hakim J. Burneet dari Inggris: "Anda akan digantung bukan karena anda mencuri kuda, melainkan agar kuda-kuda lain tidak dicuri lagi".

Menurut penulis, pemerintah memang seyogyanya tidak serta merta gegabah dalam mengambil tindakan hukum, meskipun dalam ketentuan penutup perundanganundangan pangan telah ditegaskan bahwa "setiap orang dianggap mengetahuinya". Namun harus dipahami bahwa asas fiksi hukum tersebut yang bertujuan untuk mewujudkan kepastian hukum, hanyalah "senjata" yang tak berarti tanpa dibarengi "peluru" sosialisasi hukum. Konsistensi penegakan hukum bukanlah "harga mati" bagi pengedar pangan yang mengandung Formalin, Boraks maupun Rhodamin B. Perlu penelitian yang lebih mendalam, apakah prosedur peredarannya didasari oleh kesengajaan, kelalaian atau ketidaktahuan dari pelaku usaha.

Sebagai contoh faktual, produksi terasi dari Tinanggea yang mengandung Rhodamin $\mathrm{B}$ dan unsur pelengkap tahu berupa cuka yang mengandung formalin. Jika penjual di pasar yang kemudian diberikan sanksi hukum, karena memang mereka yang memasarkannya kepada konsumen, apakah sasaran penerapan sanksi yang dikehendaki hukum pangan 
seperti demikian? Adilkah penegakan hukum semacam itu?

Namun demikian, penulis juga menyadari bahwa masih ada hal-hal yang harus dibenahi oleh Balai POM dalam proses penegakan hukum atas peredaran pangan yang mengandung Formalin, Boraks dan Rhodamin B. Seyogyanya pada langkah awal dilakukan identifikasi terhadap perbuatan pelaku usaha, siapa yang mengedarkan dengan sengaja, yang lalai dan yang sama sekali tidak tahu, agar penerapan sanksi hukumnya dapat memenuhi syarat keadilan dan kepastian hukum.

Dari keseluruhan uraian penulisan dan pembahasan di atas terlihat bahwa perundang-undangan Pangan belum efektif, sehingga salah satu tujuan penting dari pembentukan hukum pangan berupa perlindungan hak-hak konsumen belum tercapai.

Tidak efektifnya perundangundangan pangan ini diakibatkan karena hukum belum membuka akses kepada masyarakat, baik dalam bentuk sosialisasi maupun penegakannya. Pemerintah harus memulai membuka katup-katup hukum khususnya UU Pangan 1996, Permenkes Nomor 722/Menkes/Per/IX/88, Permenkes Nomor 239/Menkes/Per/V/85 dan UU Perlindungan Konsumen 1999. Dengan begitu, maka pelaku usaha dan konsumen mengetahui hak-hak dan kewajibannya masing-masing. Hukum akan efektif kalau kita mau mengefektifkan hukum tersebut.

D. Penyelesaian sengketa terhadap makanan yang mengandung zat terlarang.

1. Penyelesaian sengketa melalui pengadilan

Pengadilan negeri merupakan salah satu bentuk dan wadah penyelesaian sengketa yang paling lazim dikenal oleh masyarakat. Penyelesaian sengketa melalui pengadilan ini umumnya dikenal masyarakat sebagai upaya penyelesaian sengketa melalui jalur hukum, baik dengan cara mengajukan gugatan perdata maupun tuntutan pidana.

$$
\text { Penyelesaian sengketa }
$$

melalui pengadilan dianggap lebih memberikan kepastian hukum, oleh karena lembaga peradilan memiliki petugas jurusita yang bertugas untuk melakukan sita eksekusi jika salah satu pihak ( pihak kalah) tidak melaksanakan putusan secara suka rela. Disamping itu runtuhnya aturan hukum acara ( HIR/RBG dan KUHAP ) yang mengatur proses perkara menjadikan lembaga peradilan sangat populer dibanding lembaga penyelsaian lainnya.

Meskipun demikian, tidak semua konsumen menginginkan penyelesaian sengketa melalui pengadilan. Menurut Panmud Hukum Perdata Yaitu Pak Yunus Lande, S.H dan Panmud Hukum Pidana Zainal Abidin, S.H , bahwa sampai saat ini belum ada kasus atau sengketa terhadap makanan yang mengandung bahan formalin dan boraks yang diajukan / didaftarkan ke pengadilan negeri Kendari, baik gugatan perorangan, legal standing maupun gugatan class action.

\section{Penyelesaian sengketa diluar pengadilan.}

Penyelesaian sengketa melalui cara musyawarah para pihak yang bersengketa dibawah titel Alternatif Dispute resolution (ADR). Ini adalah lembaga penyelesaian sengketa atau beda pendapat melalui prosedur yang disepekati oleh para pihak dengan cara konsultasi, negosiasi, mediasi dan konsiliasi. Sesuai dengan hasil wawancara kami baik dari pihak 
pengadilan maupun Balai POM Kendar,i sampai saat ini penyelesaian sengketa terhadap makanan yang mengandung bahan Formalin dan boraks belum pernah diselesaikan melalui dua jalur hukum tersebut. Oleh karena itu pembahasan ini kami fokus pada Balai POM kendari.

Sehubungan hal tersebut baiklah penulis akan mengulas kembali apa yang penulis kemukan bagian halaman depan, bahwa Balai POM dalam menyikapi kasus peredaran pangan yang mengandung Formalin, Boraks maupun Rhodamin B masih dalam taraf tindakan administrasi. Sanksi yang akan diberikan kepada pelaku usaha baik atas laporan masyarakat yang diterima lewat ULKI yang ada pada Balai POM maupun yang ditemukan langsung oleh pihak Balai POM. Sanksi yang akan diberikan teguran secara lisan, peringatan tertulis, perintah untuk menarik produk pangan dari peredaran hingga pemusnahan produk pangan yang dilakukan ditempat dan disaksikan oleh pelaku usaha tersebut. Apabila pihak balai POM meneruskan kasus tersebut sampai dipengadilan atau mau konsisten menegakkan perundang-undangan pangan, maka dapat dipastikan dunia usaha khususnya usaha-usaha IRT akan redup dan pelaku usaha akan gulung tikar.

\section{Kasus pangan yang mengandung zat terlarang}

Pada tanggal 19 Juni 2009 tim dari balai POM Kota Kendari meninjau/ memeriksa sarana produksi IRT yanag banyak membuat kerupuk, diketuai oleh Ibu $\mathrm{Hj}$, Sultriana Zachri, S.Si, Apt. Hasil IRT yanag berupa kerupuk itu diberi bahan tambahan agar kerupuk itu mengembang, bahan tambahan yaitu, bermerek Blane Jago yang dibeli di salah satu KUD di Konsel Palngga. Tim Balai POM mengambil semua hasil produksi kerupuk juga baham tambahan, laalu dibawa ke Balai POM untuk diambil sampling dilaboratorium Balai Pom Kota Kendari, ternyata positif baahwa bahan tambahan tersebut mengandung boraks, yang dapat menyebabkan kanker.

Tindak lanjut yang dilakukan oleh Balai POM , pengusaha IRT kerupuk dan pemilik KUD dipanggil di Kantor Balai POM dan semua hasil produksi dan Blane Jago ditarik dari peredaran dan dilarang untuk dijual lalu dimusnahkan di Kantor Balai POM Kendari. Selanjutnya diekspos dikoran yaitu pada tanggal 20 Agustus 2009, ini bertujuan agar seluruh masyarakat mengetahaui bahwa kerupuk yang dihasilkan IRT mengandung bahan zat yang terlarang. Tindak lanjut yang dilakukan oleh Tim Balai POM Kendari yaitu setiap 6 (enam) bulan usaha IRT ditinjau diadakan pemeriksaan selanjutnya.

\section{A. Kesimpulan}

\section{PENUTUP}

1. a. Bentuk suatu makanan yang mengandung zat terlarang bagi konsumen dapat diketahui melalui, pertama, stabilitas dan reaktivitas zat terlarang seperti larutan formalin akan stabil pada suhu dan tekanan normal, kedua, aspek toksiologi dan batasan paparan seperti, LD 50 (oral, tikus $)=100 \mathrm{mg} / \mathrm{kg}, \mathrm{LD} 50$ (oral, mencit ) $=42 \mathrm{mg} / \mathrm{kg}$, LD 50 (oral, marmut $)=260 \mathrm{mg} / \mathrm{kg}, \mathrm{LD}$ $50($ kulit kelinci $)=270 \mathrm{ul} / \mathrm{kg}$, LD 50 (subkutan, tikus) $=420$ $\mathrm{mg} / \mathrm{kg}$, daan LD 50 (intravena, tikus) $=87 \mathrm{mg} / \mathrm{kg}$.

b. Ukuran suatu makanan yang mengandung zat terlarang bagi konsumen dapat diketahui melalui, pertama, Bahaya paparan jangka pendek ( Akut), 
Jika terhirup maka zat tersebut berada pada konsentrasi $0,1-5,0$ bpj dapat menyebabkan iritasi pada hidung dan tenggorokan, 10-20 bpj dapat menyebabkan susah bernafaas, rasa terbakar pada hidung dan tenggorokan dan batuk 25-50 bpj dapat menyebabkan kerusakan jaringan dan luka saluran pernafasan saperti pneumotnitis dan kadangkadang edema paru. Gejala lain seperti bersin, sulit bernafas, radang kerongkongan, radang batang tenggorok, dada sesak, radang cabang batang tenggorok, sakit kepala, disfagia, sangat haus ( execessive thirsf), kelelahan, berdebar-debar, mual dan muntah. Pada konsentrasi sangat tinggi akan menyebabkan kematian. Reaksi hipersensitifistas seperti udem laring, asma bronchitis, broncitis parah. Kedua, Bahaya paparan jangka panjang (kronis), seperti jika terhirup, maka makanan yang mengandung zat terlarang dalam jangka panjang dapat menyebabkan sakit kepala, rhinntis mual, mengantuk, gangguan pernafasan, ganggung ginjal dan sensitisasi paru. Efek neuropsikologi seperti gangguan tidur, iritabilitas, ganggung keseimbangan, penurunan daya ingat, hilang konsentrasi dan perubahan kejiwaan, gangguan haid dan sterilitas kedua pada wanita. Efek produktif pada hewan.

2. Perlindungan hukum konsumen terhadap makanan yang mengandung zat terlarang dapat berupa perlindungan hukum preventif dan perlindungan hukum represif. Perlindungan hukum preventif adalah mencegah masyarakaat dari jenis makanan yang mengandung zat terlarang dan perlindungan hukum represif adalah melakukan proses pengobatan dan pencapaian kesehatan secara optimal bagi masyarakat yang telah terindikasi terhadap jenis makanan yang mengandung unsur-unsur zat terlarang.

3. Penyelesaian sengketa kasus makanan yang mengandung zat terkarang diselesaikan oleh Balai POM Kendari. Dalam menyelesaikan sengketa Balai POM Kendari menjatuhkan sanksi administrasi kepada pelaku usaha, namun sanksi tersebut tidak setimpal jika dibandingkan dengan kerugian yang harus diderita oleh konsumen. Konsumen telah mengkomsumsi makanan yang sudah tidak layak untuk dikomsumsi, dan ini sangat berbahaya untuk kesehatan jiwanya yang bisa mengakibatkan kematian. Secara langsung memang jarang kita temukan derita yang langsung dialami oleh konsumen, namun hal ini dirasakan setelah jangka waktu yang lama. Tanpa sadar bibit penyakit telah bersemayam dalam tubuh.

\section{B. Saran}

1. Diharapkan, pemberian sanksi administrasi dapat mengandung pelajaran terhadap peningkatan tanggung jawab dan kepatuhan pelaku usaha atas standar keamanan yang berlaku, sebagaimana sasaran strategis yang hendak dicapai oleh Balai POM dalam rangka mewujudkan perannya sebagai penjamin keamanan peredaran pangan.

2. Balai POM beserta lembaga-lembaga yang bergerak dibidang perlindungan konsumen, hendaknya meningkatkan kuantitas dan kualitas 
program sosialisasi hukum pangan kepada konsumen dan pelaku usaha, khususnya mengenai penyalahgunaan bahan makanan yang mengandung zat terlarang, serta bahan tambahan pangan lain yang dilarang, agar hukum dapat menyatu dengan pola kesehatan masyarakat, baik itu pelaku usaha, konsumen dan penegak hukum itu sendiri.

3. Konsumen jangan berdiam diri terusmenerus. Belajar dan pahami hukum pangan, agar konsumen menyadari bahwa hak-haknya telah dijamin oleh hukum pangan.

4. Pelaku usaha pangan harus sesegera mungkin menyadari bahwa hukum pangan dan hukum perlindungan konsumen bukan hanya sekedar aturan tingkah laku yang tak bermakna, melainkan merupakan kebutuhan sosial yang akan menciptakan suasana yang kondusif dalam berusaha.

5. Di himbau kepada pihak Pemerintah Sulawesi Tenggara khusunya di Kendari sudah seharusnya dibentuk suatu lembaga Badan Penyelesaian Sengketa Konsumen (BPSK.

\section{DAFTAR PUSTAKA}

Aan Aswari, Perlindungan Hukum Para Pihak Dalam Transaksi Eletronik (E-Commerce) Di Kota Makassar, 2012. Tesis, Program Pasca Sarjana Universitas Muslim Indonesia, Makassar.

Achmad Ali, 1990, Mengembara di Belantara Hukum, Hasanuddin University Press, Ujung Pandang. , 1996, Menguak Tabir Hukum, Chandra Pratama, Jakarta. , 1998, Menjelajahi Kajian Empiris terhadap Hukum, Yasrif Watampone, Jakarta.

Ahmadi Miru dan Sutarman Yodo, 2004, Hukum Perlindungan Konsumen, PT. Raja Grafindo Persada, Jakarta.
Aminuddin Salle, 1999, Hukum Pengadaan Tanah untuk Kepentingan Umum, Disertasi, Program Pascasarjana Universitas Hasanuddin, Makassar.

Chairuddin, OK, 1991, Sosiologi Hukum, Sinar Grafika, Jakarta.

Lawrence M. Friedman 1977, Law and Society, Prentice Hall, New Jersey. Mariam Daruz Badrulzaman, 1980, Perjanjian Baku (Standar)

Perkembangannya di Indonesia, Alumni, Bandung.

Muchtar Kusumaatmadja, 1976, Hubungan Timbal Balik antara Hukum dengan KenyataanKenyataan Masyarakat, BPHN, Jakarta.

Nasution, A.Z, 1995, Konsumen dan Hukum, Pustaka Sinar Harapan, Jakarta.

Nurhaedah, Nurhaedah. "Analisis Hukum Terhadap Asuransi Kendaraan Bermotor Bagi Pemilik Kendaraan Sebagai Tertanggung." Pleno Jure 4.5 (2015): 28-41.

Rusli Effendy, dkk, 1991, Teori Hukum, Hasanuddin University, Ujung Pandang.

Satjipto Rahardjo, 1986, Hukum dan Masyarakat, Angkasa, Bandung. Siahaan, N.H.T, 2005, Hukum Konsumen (Perlindungan Konsumen dan Tanggung Jawab Produk), Panta Rei, Jakarta.

Shidarta, 1994, Hukum Perlindungan Konsumen di Indonesia, Grasindo, Jakarta.

Soerjono Soekamto, 1982, Kesadaran Hukum dan Kepatuhan Hukum, Rajawali Pers, Jakarta.

, 1983, Faktor-Faktor yang Mempengaruhi Penegakan Hukum, CV. Rajawali, Jakarta. , 1985, Efektivitas Hukum dan Peranan Sanksi, Remaja Karya, Bandung. 
Soerjono Soekamto dan Mustafa Abdullah, 1987, Sosiologi Hukum dalam Masyarakat, Rajawali Pers, Jakarta.

Soleman B. Taneko, 1993, Pokok-Pokok Studi Hukum dalam Masyarakat, Raja Grafindo Persada, Jakarta.

Sudaryatmo, 1999, Masalah Perlindungan Konsumen di Indonesia, Citra Aditya Bakti, Bandung.

Sunaryati Hartono, 1991, Politik Hukum Menuju Satu Sistem Hukum Nasionat, Alumni, Bandung.

Susanti Adi Nugroho,2008, Proses Penyelesaian Sengketa konsumen di Tinjau dari Hukum Acara Serta Kendala

Implementasinya, Kencana

Prenada Media Group.

Yunus, Ahyuni. "Aspek Keadilan Perjanjian Baku (Standard Contract) Dalam Perjanjian Kredit Perbankan." Maleo Law Journal 1.1 (2017): 106-118.

Yusuf Shafie, 2004, Perlindungan Konsumen, Citra Aditya Bakti, Bandung.

$\underline{\text { Sumber-sumber lain : }}$
Badan POM, Peraturan di Bidang Pangan, TOT Penyuluhan Keamanan Pangan, Hotel Cendrawasih 18-23 Mei 2003, Kendari.

, Klasifikasi Bahan Pangan Berdasarkan Resiko Keamanan Pangan, TOT District Food Inspector Lanjutan, Hotel Kartika 11-16 Juni 2003, Kendari. , 2003, Kebijakan dan Program Nasional Keamanan Pangan Industri Rumah Tangga, Direktorat Surveilan dan Penyutuhan Keamanan Pangan, Deputi Bidang Pengawasan Keamanan Pangan dan Bahan Berbahaya, Jakarta.

, Volume 07/Tahun IV/2005, Keamanan Pangan, Buletin Jakarta.

, Volume : 4 Edisi 1, Februari 2006, PenyaJahgunaan Fonnalin untuk Pengawet Mie Basah, Tahu dan Ikan, Warta, Jakarta. www.depkes.go.id, Januari 2004 www.pom.go.id, 30 Desember 2005, Berita Aktual Formalin. 